Available Online : https://proceeding.researchsynergypress.com/index.php/cset/index

RSF Conference Series: Engineering and Technology

ISSN 2809-6843 (Online) | 2809-6878 (Print)

Volume 1 Number 1 (2021): 597-602

\title{
Identification of Buried "Archeological" Objects in the Area around Kedulan Temple using Geomagnetic Methods
}

\author{
Firdaus Maskuri' ${ }^{1}$, Wrego Seno Giamboro', Wahyu Hidayat ${ }^{1}$ \\ ${ }^{1}$ Geophysical Department FTM UPN “Veteran” Yogyakarta, Indonesia
}

\begin{abstract}
Temple is a religion place for ancient culture, Yogyakarta have many incridible temples one of the biggest is Prambanan temple. $2 \mathrm{Km}$ to the north west direction from Perambanan temple located the Kedulans temple who still on renovation projects. Kedulan Temple is located in Tirtomartani Village, Kalasan District, Sleman, Yogyakarta Special Region, at coordinates $7^{\circ} 44^{\prime} 28^{\prime \prime}$ South Latitude and $110^{\circ} 28^{\prime} 5^{\prime \prime}$ East Longitude, with an altitude of 168, 45 meters above sea level. Kedulan Temple was found in a collapsed state and buried volcanic material from Mount Merapi. Based on the results of a stratigraphic study conducted by Pramumijoyo, et al., (2005) this temple is covered by 8 meters thick lava which is composed of 14 layers of sediment. To obtain information on the existence of archaeological objects that are still buried around the temple in this study, geophysical measurements were carried out using the geomagnetic method which aims to determine the potential for buried archaeological objects in this case assumed to be igneous rocks that have contrasting susceptibility. Based on the geomagnetic signal analytic map obtained, there is a magnetic anomaly which is suspected to be a hidden temple object which is bordered by a black line which is about 50 meters to the east of Kedulan Temple. This assumption is based on a high magnetic anomaly value $>480 \mathrm{nT}$ which is thought to originate from the temple rock object in the form of andesite rock.
\end{abstract}

Keywords: Kedulan Tample, Geomagnetic, Archeology

\section{INTRODUCTION}

This is an open access article under the CC-BY-NC license

Kedulan Temple is located in Tirtomartani Village, Kalasan District, Sleman, Special Region of Yogyakarta, located at coordinates $7^{\circ} 44^{\prime} 28^{\prime \prime}$ South Latitude and $110^{\circ} 28^{\prime} 5^{\prime \prime}$ East Longitude, with an altitude of 168, 45 meters above sea level (Figure 1). Kedulan Temple was found in a collapsed state and buried volcanic material from Mount Merapi. Based on the results of a stratigraphic study conducted by Pramumijoyo, et al., (2005) this temple is covered by 8 meters of lava which is composed of 14 layers of sediment (Figure 2). Kedulan Temple was first discovered in late 1993 by sand miners in the area. Miners found an arrangement of stone blocks at a depth of three meters. These findings were then reported to the Yogyakarta Special Region Cultural Heritage Preservation Center. The report was then followed up by conducting rescue excavation activities. During excavation, the condition of the temple has collapsed, the stones that make up the temple are scattered, this is thought to have been caused by the lava of Mount Merapi and was buried at a depth of eight meters below the ground surface (Sismanto, 2004). From the following sentences can be concludes that this research is very important for the Kedulan temple heritage as a early information for the buried temple to excavated process.

\section{LITERATURE REVIEW}

Research on Kedulan Temple has been carried out by several researchers, Sismanto (2004) researched in this area using the VLF electromagnetic method, the results of the researchers suspected that there were anomalies that were suspected to be temples. Hussein, et al. (2010) investigated the excavation area of the Kedulan temple using the Georadar method. Based on the results of research by Husein, et al (2010), it was stated that the structure of the Kedulan Temple has a chaotic reflection pattern on the radargram cross-section, where the temple structure is immersed as far as 7 meters below the surface. Geological investigations in the excavation area carried out by the Department of Geological Engineering, Gadjah Mada University Yogyakarta, based on excavation results showed 14 layers of fluvial-volcanic deposits covered the site with an average thickness of $7 \mathrm{~m}$ (Pramumijoyo et al., 2005) (Figure 2). This fact shows that natural disasters such as volcanic eruptions damaged and destroyed the temple complex (Department of Culture and Tourism of Sleman Regency, 2004; Pramumijoyo et al., 2005; Mulyaningsih, 1999; 2006). 


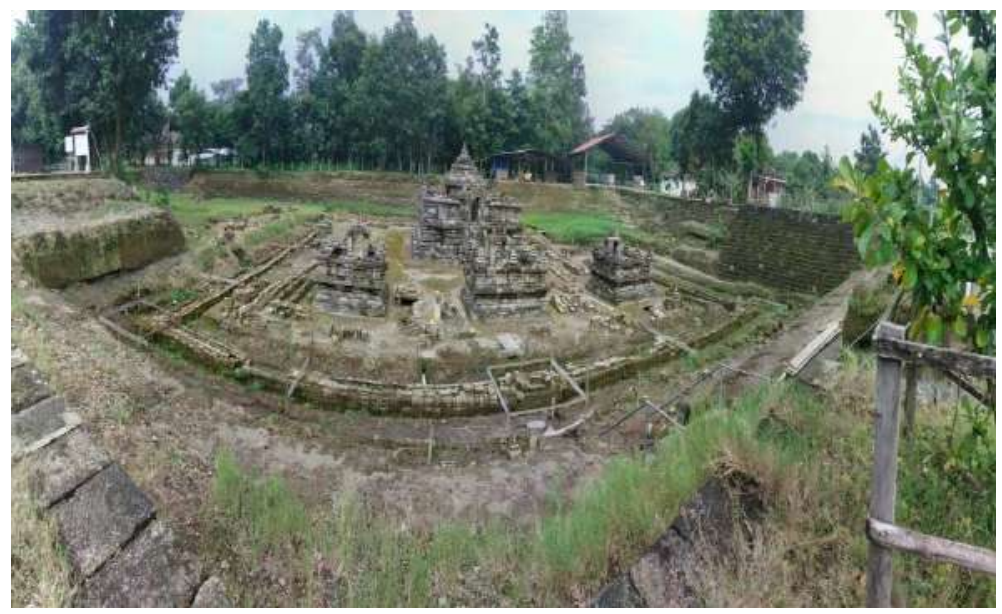

Figure 1. Kedulan Temple archaeological building structure (Private document, 2021)

The geomagnetic method is sensitive to the contrast of andesite, which is the main material for the temple rocks, with the surrounding rocks dominated by fluvio-volcanic deposits from the eruption of young Mount Merapi in the form of sandstone and gravel. It is hoped that the results of the geomagnetic method will be able to provide the distribution of temple rocks that are still buried below the surface.

\begin{tabular}{|c|c|c|c|}
\hline Lithology & $\begin{array}{l}\text { Thickness } \\
(\mathrm{cm})\end{array}$ & Layer unit & Description \\
\hline \multirow{4}{*}{ W- } & $<20$ & 15 & \multirow{4}{*}{ Intercalations of fluvial sand and pyroclastic tuf } \\
\hline & $<20$ & 14 & \\
\hline & $<40$ & 13 & \\
\hline & $<40$ & 12 & \\
\hline \multirow{4}{*}{ 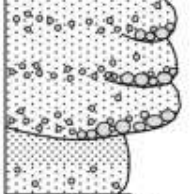 } & \multirow{3}{*}{250} & 11 & \multirow{3}{*}{$\begin{array}{l}\text { 2-3 sequences of lahar deposits, composed of normal } \\
\text { grading of boulder to sand. Floating fragments are } \\
\text { common near the bottom. }\end{array}$} \\
\hline & & 10 & \\
\hline & & 9 & \\
\hline & 150 & 8 & $\begin{array}{l}\text { Normal grading of coarse to medium sand. Lamination and } \\
\text { planar cross beds are common at the top. }\end{array}$ \\
\hline \multirow{4}{*}{$\frac{1}{-1}$} & $<80$ & 7 & $\begin{array}{l}\text { Gravelly sand, mainly composed of floating angular } \\
\text { scorian andesite fragments. }\end{array}$ \\
\hline & $<6$ & 6 & Black clay with some small tree trunks. \\
\hline & $>30$ & 5 & Reddish brown sandy clay with paleosoil $<10 \mathrm{~cm}$. \\
\hline & $80-200$ & 4 & $\begin{array}{l}\text { Graded bedding gravelly sand. Lamination and planar } \\
\text { cross beds are common at the top. }\end{array}$ \\
\hline \multirow{3}{*}{ 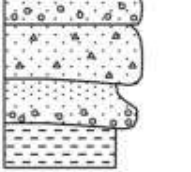 } & $80-160$ & 3 & Massive gravelly sand with angular andesite fragments. \\
\hline & $40-50$ & 2 & Graded bedding coarse to medium sand. \\
\hline & $>30$ & 1 & Reddish brown clayey fine-sand. \\
\hline
\end{tabular}

Figure 2. Kedulan temple stratigraphic column (Modified from Pramumijoyo et al., 2005)

\section{RESEARCH METHODOLOGY}

The Earth is huge magnetics object who have indepent magnetic field which is called earth's magnetic field.

The earth's magnetic fields become a primary inductor for the rocks in the earth's crust. The geomagnetic method measures the rocks magnetic intensity distribution in the sub surface. The sub surface rocks have opposite magnetic field charges are separated by a certain distance which is defined as the following magnetic field strength:

$$
\frac{H}{q_{2}}=\stackrel{F}{=}{ }_{\mu_{0} r^{2}}^{q_{1}} \stackrel{r}{r}
$$


Where,

$$
\begin{array}{ll}
H & =\text { magnetic field strength }(T), \\
F & =\text { magnetic force }(\mathrm{N}), \\
q 1 \text { and } q_{2} & =\text { object quantity, } \\
0 & =\text { permeability of free space and } \\
\mathrm{r} & =\text { distance between } \mathrm{m} 1 \text { and } \mathrm{m}^{2}
\end{array}
$$

As a result of the induced primary magnetic field of the earth, the sub surface rock generates a secondary magnetic field which is measured in the magnetic intensity of the rocks $(I)$. The magnetic intensity of rocks has an important role in the measurement of geomagnetic methods, where each rock has a different level of magnetic intensity which is influenced by its susceptibility $(k)$ properties.

$$
I=k H
$$

The magnetic's susceptibility is variate ini every rock type, the igneous rocks have a highest average susceptibility value and the sediment rocks and soils have a lowest average susceptibility. The susceptibility value of the rocks difined by Telford et al. (1990) in table 1.

Table 1. Rocks and minerals susceptibility (Telford et al, 1990)

\begin{tabular}{lcc}
\hline \multirow{2}{*}{ Material } & \multicolumn{2}{c}{ Susceptibility $\mathbf{~} \mathbf{1 0}^{\mathbf{3}}(\mathbf{S I})$} \\
\cline { 2 - 3 } & Range & Average \\
\hline Limestone & $0-3$ & 0,3 \\
Sandstone & $0-20$ & 0,4 \\
Shales & $0,01-15$ & 0,6 \\
Phyllite & & 1,5 \\
Quartzite & & 4 \\
Porphyry & $0,3-200$ & 60 \\
Basalt & $0,2-175$ & 70 \\
Diorite & $0,6-120$ & 85 \\
Andesite & & 160 \\
Quarzt & & $-0,001$ \\
Clays & & 0,2 \\
Chalcopyrite & & 0,4 \\
Pyrite & $0,05-5$ & 1,5 \\
Hematite & $0,5-35$ & 6,5 \\
Pyrrhotite & $1-6000$ & 1500 \\
Ilmenite & $300-3500$ & 1800 \\
Magnetite & $1200-19.200$ & 6000 \\
\hline
\end{tabular}

\section{FINDING AND DISCUSSION}

The research location of Kedulan Temple is in Kalasan District, Sleman Regency, Yogyakarta Special Region Province, $2 \mathrm{~km}$ east of Sambisari Temple and $1.5 \mathrm{~km}$ north of Prambanan Temple. Field measurements were carried out for 3 (three) days on August 16-18, 2021 using the geomagnetic method. Measurements were carried out in the Kedulan Temple area as many as 170 measurement points using the geomagnetic method (Figure 3). 
RSF Conference Series: Engineering and Technology

Vol 1 (1), 597-602

Identification of Buried "Archeological" Objects in the Area around Kedulan Temple using Geomagnetic Methods Firdaus Maskuri, Wrego Seno Giamboro, Wahyu Hidayat

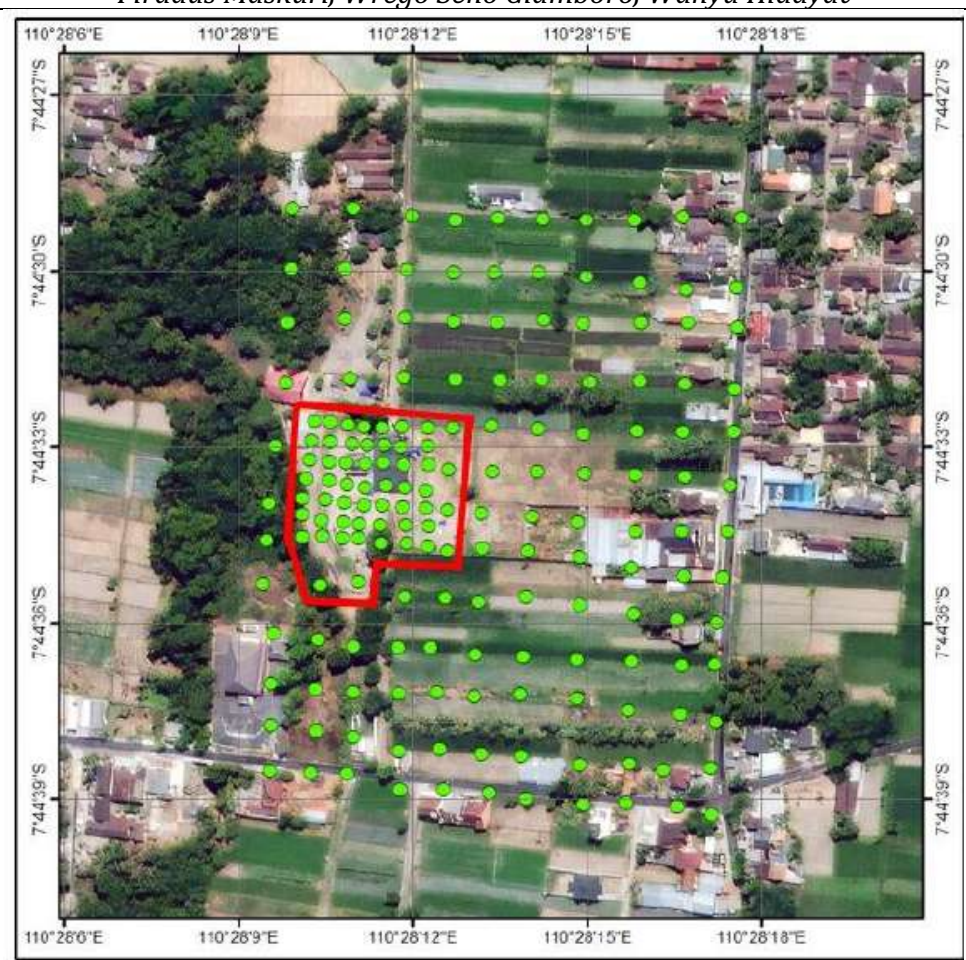

Figure 3. Geomagnetic method measurement point location map

This research begins with a study of literature relevant to the research plan carried out in terms of archeology, geology and geophysics to obtain information about the research object being sought and the appropriate measurement method. In this research activity, geomagnetic method field data acquisition was carried out. Data processing is carried out by calculating and making a map of the total magnetic field intensity with a signal analytic filter applied to eliminate the dipole effect on the total magnetic field intensity map so that a signal analytical map is produced. Signal analytic maps are interpreted for areas that have the potential for buried archaeological objects to be found.

Through the measurement of the geomagnetic method, the result is a map of the intensity of the magnetic anomaly. The salty magnetic anomaly intensity map has dipole magnetic field anomaly information. For this reason, a signal analytic filter is carried out to get a more actual magnetic anomaly position. The result of the signal analytic filter is in the form of a signal analytic map showing magnetic field anomalies originating from below the surface (Figure 4). 


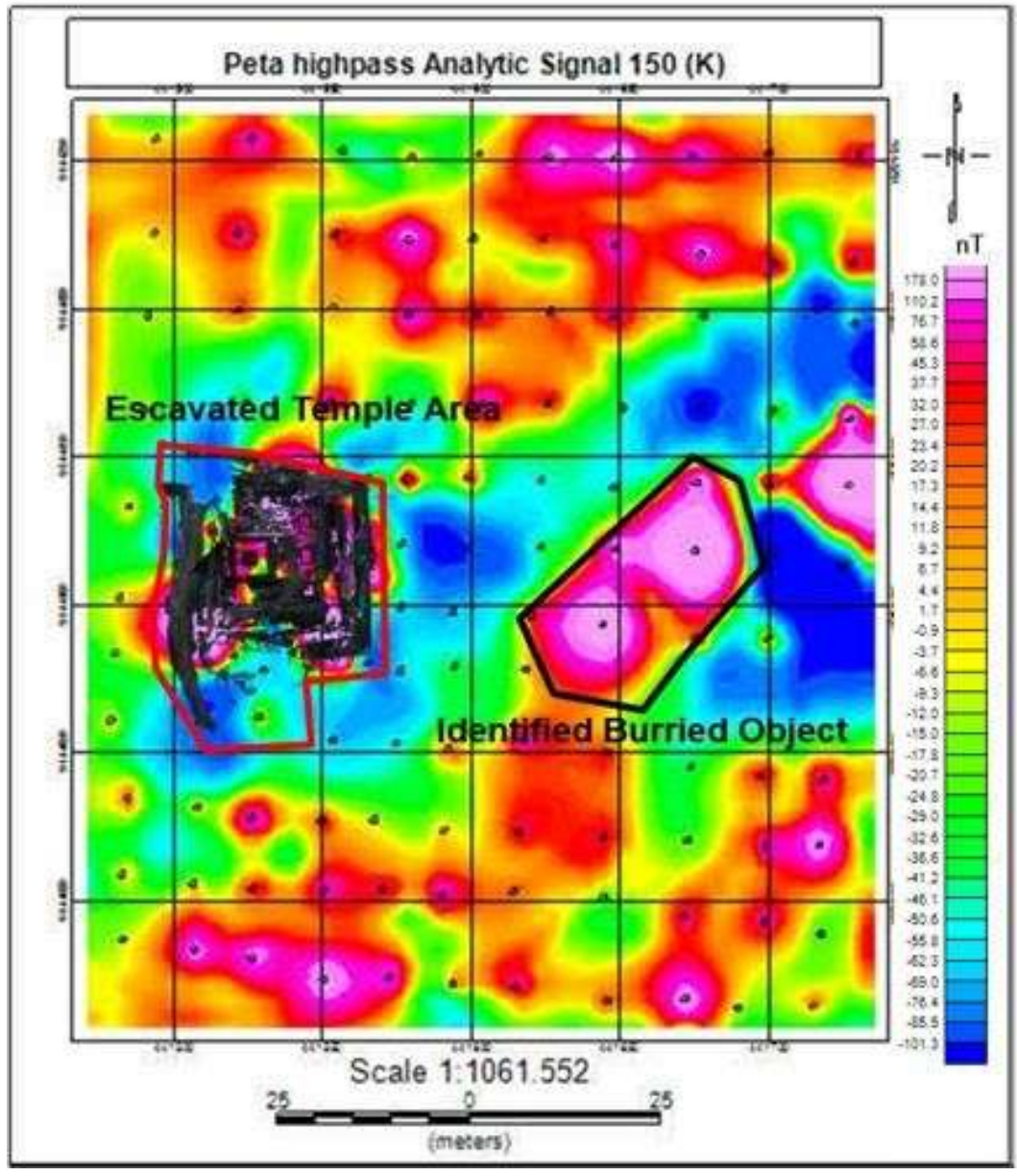

Figure 4. Geomagnetic analityc signal map

Based on the geomagnetic signal analytic map obtained, there is a magnetic anomaly suspected to be a hidden temple object which is bordered by a black line (figure 5) which is about 50 meters to the east of the temple. kedulan. This assumption is based on a high magnetic anomaly value $>480 \mathrm{nT}$ which is thought to come from the temple rock object in the form of andesite rock. Andesite rock itself is a type of igneous rock that has a relatively higher magnetic intensity value and contrasts with other rocks around the study area which are volcanic fluvial deposits that have a low level of magnetic intensity. The analysis of the area suspected to be a buried temple object was also obtained based on the value of the magnetic intensity in the excavated temple area, wherein that area the magnetic intensity of the measured rocks was also quite high, namely $>480 \mathrm{nT}$.

\section{CONCLUSION AND FURTHER RESEARCH}

Based on the geomagnetic signal analytic map, an anomaly object, which is suspected to be a buried temple, is located 50 meters to the east of Kedulan Temple, with a magnetic anomaly value of $>480 \mathrm{nT}$.

\section{REFERENCES}

Aitken, M. J., 1974. Physics and Archaeology, 2nd edn. Oxford: Clarendon.

Becker, H., 1997. Hochauflösende Magnetik am Beispiel der archäologischen Prospektion. In Beblo, M. (ed.), Umweltgeophysik. Berlin: Ernst und Sohn, pp. 59-70

Benech, C., 2005. Étude des plans d'urbanisme antiques. Dossiers d'Arche'ologie, 308, 12-19.

Clark, A., 1996. Seeing Beneath the Soil: Prospecting Methods in Archaeology. London: Batsford. 
Identification of Buried "Archeological" Objects in the Area around Kedulan Temple using Geomagnetic Methods Firdaus Maskuri, Wrego Seno Giamboro, Wahyu Hidayat

David, A., Linford, N., Linford, P., Martin, L., and Payne, A., 2008. Geophysical Survey in Archaeological Field Evaluation, 2nd edn. Swindon: English Heritage.

Fröhlich, N., Posselt, M., and Schleifer, N., 2003. Excavating in a "blind mode". Magnetometer survey, excavation and magnetic susceptibility measurements of a multiperiod site at Bad Homburg, Germany. Archaeologia Polona, 41, 167-169.

Husein, Salahudin, Saptono B. S., Subagyo P. 2010. Georadar Investigation at the Kedulan Temple Ekcavation Site, Kalasan, Yogyakarta. Yogyakarta: Department of Geological Enginering, Faculty of Engineering, UGM.

Loke, M.H., 2004. 2D and 3D Electrical Imaging Surveys. England: Birmingham University.

Mulyaningsih, S., 2006. Geologi Lingkungan di Daerah Lereng Selatan Gunung Api Merapi pada Waktu Sejarah (Historical Time). Departemen Teknik Geologi, Sekolah Tinggi Pascasarjana Institut Teknologi Bandung, 365 p. (unpublished dissertation).

Pramumijoyo, S., M. Datun, Supangat, S. Surayati, and A. Setianto (2005) Renovation of Kedulan Temple, Yogyakarta and Geohazard Public Awareness Education. HAGI-IAGI Joint Convention Surabaya 2005, Surabaya.

Schleifer, N., 2004. Ghost features-A proposal for appropriate management and a forum for discussion. Newsletter of the International Society of Archaeological Prospection, 1, 6-9.

Schleifer, $\quad$ N., Fassbinder, J. W. E., Irlinger, W. E., and Stanjek, H., 2003. Investigation of an eneolithic chamer-group ditchsystem near Riekofen (Bavaria) with archaeological, geophysical and pedological methods. In Füleky, G. (ed.), Soils and Archaeology, Papers of the 1st International Conference on Soils and Archaeology, Sza'zhalombatta, Hungary, $30 \quad$ May-3 June 2001. Oxford: Archaeopress. British Archaeological Reports, International Series 1163, pp. 59-63.

Scollar, I., Tabbagh, A., Hesse, A., and Herzog, I., 1990. Archaeological Prospecting and Remote Sensing. Cambridge: Cambridge University Press.

Sismanto. (2004). Laporan Teknis Pengukuran Pada Komplek Situs Candi Kedulan Dengan Menggunakan Metode VLF. Yogyakarta: Lab. Geofisika, Jurusan Fisika, Fakultas Matematika dan Ilmu Pengetahuan Alam, UGM.

Telford, W.M., L.P. Geldart., R.E. Sheriff. (1990). Applied Geophysics Second edition. New York. Cambridge. 